\title{
ВИКОРИСТАННЯ ХРОМ-ФЕРИТНОГО КАТАЛІЗАТОРА ДЛЯ ОЧИЩЕННЯ ДИМОВИХ ГАЗІВ МЕТАЛУРГІЙНОГО ВИРОБНИЦТВА
}

\author{
С.Д. Довголап, О.І. Іваненко \\ Національний технічний університет України \\ «Київький політехнічний інститут ім. Ігоря Сікорського», \\ пр. Перемоги, 37, Київ, 03056, Україна, \\ e-mail: s.dovholap@gmail.com
}

3 екологічної точки зору СО - високотоксичний газ, небезпечний для життя, який призводить до гіпоксії, задухи і раптової смерті. Летальність від отруєння СО, що складає 17,5 \% від загальної кількості інгаляційних отруєнь, становить найбільшу частку зареєстрованих смертельних інтоксикацій газами в світі у випадках, не пов'язаних 3 пожежею. Передбачається, що число жертв несмертельного отруєння, які страждають від постійного розладу нервової системи, перевищує вищезазначену цифру. Величина небезпеки для здоров'я, фатального і не фатального характеру, яка надходить від монооксиду вуглецю, $є$ величезною, і отруєнь відбувається набагато більше, ніж це зараз виявляється.

Найбільша кількість викидів монооксиду вуглецю спостерігається на індустріально розвинених територіях з високою концентрацією видобувних і обробних підприємств. Тому надзвичайно актуальним $є$ розробка науково-технічних рішень, спрямованих на більшу екологізацію металургійного виробництва шляхом зниження викидів димових газів, що містять $\mathrm{CO}$, в атмосферне повітря.

Одним із конструктивних рішень проблеми очистки димових газів багатокамерних печей випалювання електродних заготовок від монооксиду вуглецю може бути розміщення у вогневих каналах цих печей контейнерів 3 каталізатором у камерах, що підігріваються димовими газами [1]. Таким чином, метою даної роботи є розробка каталізаторів окиснення СО для вирішення важливої наукової проблеми техногенного забруднення навколишнього середовища підприємствами з виробництва електродів.

Загальна кількість застосувань наноферитних технологій для каталітичних цілей все ще відносно невелика, тому розробка ефективних рішень може стати ідеальною дослідницькою нішею щодо впровадження у виробництво феритних наноматеріалів для знешкодження монооксиду вуглецю димових газів.

Феритні технології досить ефективно використовуються у процесах очищення стічних вод від іонів важких металів [2]. Тобто застосування феритного шламу в якості цінної сировини для каталізаторів окиснення СО має хороший потенціал для використання в екологічних цілях.

У результаті проведення порівняльних аналізів найперспективнішим природоохоронним заходом можна вважати використання в якості каталізаторів феритів різного походження. Перевагами феритів порівняно з іншими каталізаторами є низька чутливість до каталітичних отрут, відсутність проблем з їх експлуатацією та утилізацією, нетоксичність і обмеженість біодеградабельності. Найоптимальнішим каталізатором серед оглянутих каталізаторів на 
основі феритових технологіях є хром-феритовий каталізатор.

Процес отримання хром-феритовий каталізатора $\left(\mathrm{Cr}^{6+}: \mathrm{Fe}^{2+}=1: 15\right)$ на основі цеоліту [3] полягав в обробці природного матеріалу сумішшю розчинів $0,028 \mathrm{M} \mathrm{K}_{2} \mathrm{Cr}_{2} \mathrm{O}_{7}$ та $0,332 \mathrm{M} \mathrm{FeSO}_{4}$ протягом 1 год, після чого осад фериту хрому осаджували на цеоліті $25 \%$ розчином $\mathrm{NH}_{4} \mathrm{OH}$ за реакціями:

$$
\begin{gathered}
\mathrm{Cr}_{2} \mathrm{O}_{7}{ }^{2-}+2 \mathrm{OH}^{-} \rightarrow 2 \mathrm{CrO}_{4}{ }^{2-}+\mathrm{H}_{2} \mathrm{O} \\
2 \mathrm{~K}_{2} \mathrm{CrO}_{4}+9 \mathrm{Fe}(\mathrm{OH})_{2} \rightarrow 3 \mathrm{Fe}_{3} \mathrm{O}_{4} \downarrow+2 \mathrm{Cr}(\mathrm{OH})_{3} \downarrow+4 \mathrm{KOH}+4 \mathrm{H}_{2} \mathrm{O},
\end{gathered}
$$

та витримували протягом 24 год. Після цього модифікований цеоліт відділяли від водної фази декантацією, промивали та сушили на повітрі до постійної маси.

Експериментальна установка (рис. 1) включає термокамеру (8), що складається з металевої трубки з нержавіючої сталі (9) та керамічної трубки (10) з нагрівальним елементом (11), в якій за допомогою термопар (12) та термореле (14) підтримується за допомогою елемента (11) задана температура. Зразок каталізатора у циліндричному контейнері (13) поміщали в металеву трубку (9) таким чином, щоб виключити проходження газової суміші повз

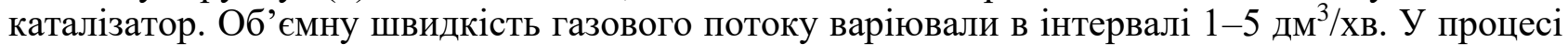
нагрівання постійно контролювали склад газової суміші на вході та виході з термокамери. Концентрацію продуктів реакції аналізували за допомогою газоаналізатора (2). Безпосередньо перед проведенням каталітичного експерименту зерно каталізатора піддавали термообробці за температури $450{ }^{\circ} \mathrm{C}$ протягом 2 годин. Перед та після нагрівання і охолодження визначали втрату маси каталізатора. Каталітичну очистку газової суміші від CO досліджували в інтервалі $200-400^{\circ} \mathrm{C}$. Концентрація монооксиду вуглецю в початковій газовій суміші на вході в реактор дорівнювала 1,1 об. \%.

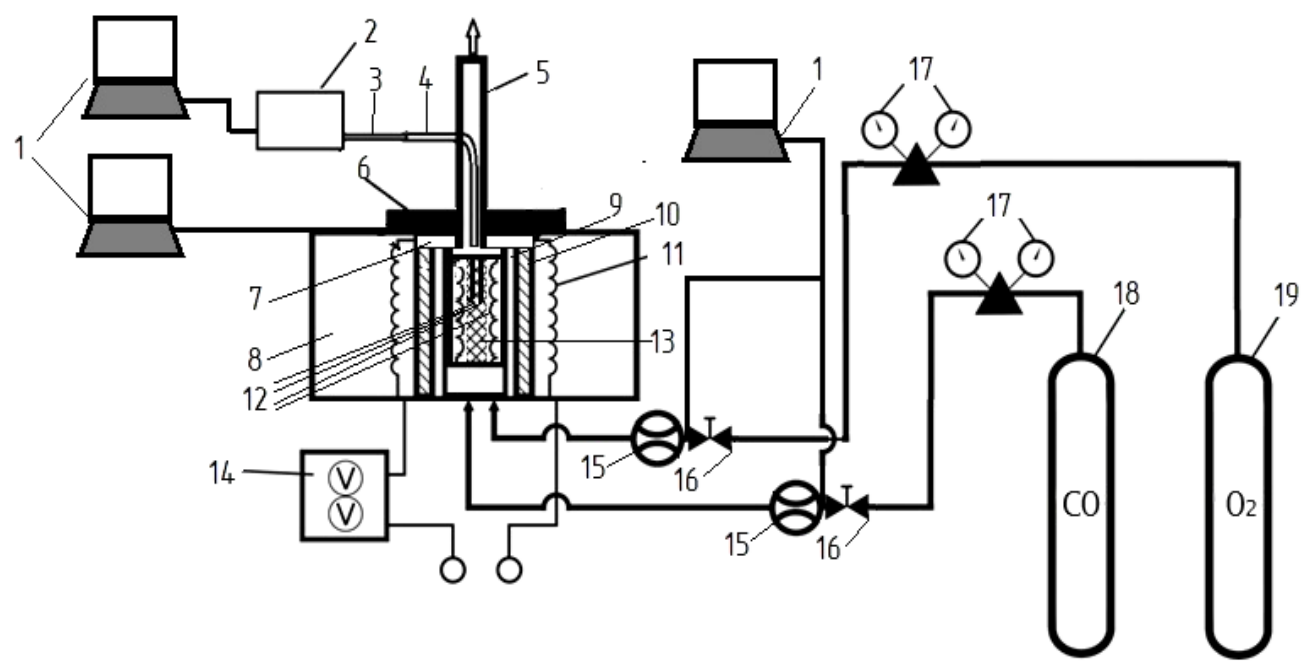

Рисунок. Схема експериментальної установки для вивчення процесів каталітичного окиснення монооксиду вуглецю: 1 - цифровий інтерфейс вимірювань; 2 - газоаналізатор VARIO PLUS industrial analyzer MRU air fair; 3 - газовідбірник газоаналізатора; 4 - трубка для відбору газової суміші 3 камери в газоаналізатор; 5 відведення газової суміші; 6 - металева прокладка; 7 - азбестова прокладка; 8 термокамера; 9 - трубка із нержавіючої сталі; 10 - керамічна трубка; 11 - нагрівальний елемент; 12 - термопари; 13 - контейнер для каталізатора із сітки з нержавіючої сталі;

14 - регулятор температури; 15 - газові витратоміри; 16 - регулюючі клапани; 17 редуктори; 18 - балон із монооксидом вуглецю; 19 - балон із повітрям 
Ступінь окиснення монооксиду вуглецю розраховували за формулою:

$$
X_{C O}=\frac{C_{C O}^{\mathrm{BX}}-C_{C O}^{\mathrm{Bux}}}{C_{C O}^{\mathrm{BX}}} \cdot 100 \%
$$

де $C_{C O}^{\mathrm{BX}}-$ об'ємна частка СО на вході в реактор, \%; $C_{C O}^{\mathrm{Bux}}-$ об'ємна частка $\mathrm{CO}$ на виході $з$ реактору, \%.

Дослідження процесу окислення СО в газовій суміші в порожньому реакторі показало, що в усьому інтервалі температур $\left(200-400{ }^{\circ} \mathrm{C}\right)$ ступінь перетворення монооксиду вуглецю за відсутності каталізатора дорівнювала $0 \%$.

В результаті проведених досліджень було встановлено, що максимальна ступінь окислення $\mathrm{CO}$ з використанням різних типів феритних каталізаторів досягалася при температурі $390{ }^{\circ} \mathrm{C}$. Найефективнішим виявився хром-феритний каталізатор у порівнянні 3 мідь-феритовим каталізатором та феритовим каталізатором ефективність яких наведена у роботі [4], при використанні хром-феритного каталізатора конверсія СО за температури $390{ }^{\circ} \mathrm{C}$ складала 82,4 $\%$.

Слід зазначити, що хром-феритний каталізатор показав задовільні результати на початку вимірювання при температурі $200{ }^{0} \mathrm{C}$. Ефективність каталізатора дорівнювала 49 \%, що була вища, ніж ефективність інших феритних каталізаторів на основі дослідження наведеного у роботі [4], при максимальній температурі випробувань. Також значний приріст ефективності окислення відбувався за температури $275{ }^{\circ} \mathrm{C}$ до $325{ }^{\circ} \mathrm{C}$, також спостерігався різкий стрибок в окисленні при $275{ }^{0} \mathrm{C}$ з $55 \%$ до $73 \%$, що вказує на оптимальний температурний режим використання хром-феритного каталізатора в діапазоні температур з $325{ }^{\circ} \mathrm{C}$ до $390{ }^{\circ} \mathrm{C}$.

В результаті досліджень було визначено, що хром-феритний каталізатор є ефективним для конверсії CO димових газів та підтверджує перспективність використання в якості каталізаторів феритів з наперед заданою ефективністю. Перевагами даного каталізатору є його інертність та стійкість у довкіллі, що не буде створювати проблем з утилізацією після використання.

\section{Література:}

1. Ivanenko O., Trypolskyi A., Khokhotva O., Strizhak P., Leleka S., Mikulionok I. The kinetic parameters of the smoke gases purification process from carbon monoxide on a zeolite-based manganese oxide catalyst // Eastern-European Journal of Enterprise Technologies. 2020. № 6/6(108). P. 50-58.

2. Lou J. C., Chang C. K. Catalytic oxidation of $\mathrm{CO}$ over a catalyst produced in the ferrite process // Environmental Engineering Science. 2006. № 23(6). P. 1024-1032.

3. Радовенчик В. М., Іваненко О. І., Радовенчик Я. В., Крисенко Т. В. Застосування феритних матеріалів в процесах очищення води / Монографія. Біла Церква: Видавництво О. В. Пшонківський, 2020. 215 с. ISBN 978-617-604-065-2.

4. Ivanenko O., Gomelya N., Shabliy T., Trypolskyi A., Nosachova Y., Leleka S., Trus I., Strizhak P. Use of Metal Oxide-Modified Aerated Concrete for Cleaning Flue Gases from Carbon Monoxide//Journal of Ecological Engineering 2021, 22(5), 104-113 